\title{
ACUTE AND SUB-ACUTE TOXICITY STUDIES ON Combretum dolichopetalum ENGL. \& DIELS LEAVES
}

\author{
Chinedum U. Emelike ${ }^{1,2}$, Ugochukwu S.B. Anyaehie ${ }^{2}$, Edorisiagbon E. Iyare ${ }^{2}$, Chiemeziem A. Obike ${ }^{3}$, Chinedum Eleazu ${ }^{4,5 *}$, \\ Chukwuma Chukwu ${ }^{4}$ \\ ${ }^{1}$ Department of Physiology, Faculty of Basic Medical Sciences, College of Medicine, Alex Ekwueme Federal University, Ndufu-Alike, \\ Abakaliki, Ebonyi State, ${ }^{2}$ Department of Physiology, Faculty of Basic Medical Sciences, College of Medicine, University of Nigeria, Enugu \\ Campus, Enugu, ${ }^{3}$ Department of Biochemistry, Michael Okpara University of Agriculture Umudike, Umuahia, Abia State, ${ }^{4}$ Department of \\ Chemistry/Biochemistry, Faculty of Sciences, Alex Ekwueme Federal University, Ndufu-Alike, Abakaliki, Ebonyi State, Nigeria, ${ }^{5}$ Department \\ of Physiology, School of Medical Sciences, Universiti Sains Malaysia, Kelantan, Malaysia
}

*Corresponding author, E-mail: eleazon@yahoo.com

\begin{abstract}
We studied the acute and sub-acute toxicity of Combretum dolichopetalum leaves in experimental mice and rats respectively using standard techniques. The $\mathrm{LD}_{50}$ of the methanol extract of Combretum dolichopetalum leaves as carried out in experimental mice was obtained as more than $5000 \mathrm{mg} / \mathrm{kg}$ body weight. Administration of graded doses (100, 200, 400 and $800 \mathrm{mg} / \mathrm{kg}$ ) of the extract for 21 days resulted in increases in body weights, white blood cells (WBC), Neutrophils, red blood cells (RBC), packed cell volume (PCV), haemoglobin (HGB), mean corpuscular volume (MCV) and mean cell haemoglobin ( $\mathrm{MCH}$ ) of the rats; but did not affect $(P>0.05)$ their monocytes, mean cell haemoglobin concentration ( $M C H C)$, platelet $(P L T)$ levels. All doses of the extract did not affect $(P>0.05)$ the sodium, potassium, chloride, bicarbonate, urea, creatinine, total and conjugated bilirubin, alanine and aspartate amino transaminase, aspartate amino transaminase, alkaline phosphatase activities; relative liver and kidney weights of the rats, a finding that was corroborated by histology of the liver and the kidney. The extract at $100 \mathrm{mg} / \mathrm{kg}$ had no effect on the PCV and HB of the rats. The study suggested the therapeutic potentials of Combretum dolichopetalum as a blood booster. Finally, the study revealed the safety in the usage of Combretum dolichopetalum leaves in Nigerian ethnomedicine.
\end{abstract}

Key words: ethnopharmacology; Combretum dolichopetalum; toxicology; herbal medicine; nutraceutical; pharmacotherapy

\section{Introduction}

For several years, traditional herbal medicines have been utilized all over the world to treat diseases and promote health $(1,2)$. In view of this, the World Health Organization has come to recognize the importance of traditional/herbal medicines in the maintenance of human health. In addition, the World Health Organization estimated that nearly $80 \%$ of the human population worldwide, especially people residing in the developing countries rely on traditional herbal medicines for their health care needs (1).

Received: 1 June 2019

Accepted for publication: 3June 2020
Irrespective of the growing popularity and perceived safety of herbal medicines, recent studies have shown that several medicinal plants that are being used as traditional medicines for the maintenance of human health and management of several diseases have adverse effects (3). This has therefore generated concerns about the potential toxicity that could arise from short and long-term exposure to such medicinal plants. To mitigate this, acute and sub-acute or sub-chronic toxicity studies on medicinal plants and their products are recommended as a way of assuring humans of the safety of exposure to these herbal medicines and to establish their safety margins (4).

The use of herbal medicines for the maintenance of health and treatment of diseases is a 
common practice in Nigeria (5) and Combretum dolichopetalum Engl. \& Diels (Combretaceae) leaf is one of such plants that are used in Nigerian and African traditional medicine for the maintenance of human health and treatment of a wide array of diseases.

The plant is commonly found in the Eastern part of Nigeria. It is known as "achichanza" (food of the sun bird) in Igbo land and "okoso" in Edo Nigeria (6). Some of the folkloric medicinal uses of the roots of this plant in Nigerian and African ethnomedicine include: relief of menstrual pain, enhancement of labour, facilitation of the removal of placenta after delivery, promotion of rich milk supply after delivery, treatment of burns and skin infections, whereas the decoction is taken as a purgative (7-9) while the folkloric and pharmacological proeprties of the leaves of this plant in Nigerian ethnomedicine include: Wound healing (10), antiulcer (11), antidiarrhea activity (12), relief of menstrual pain and enhancement of labour (Personal communication).

The antiulcer, anti-hepatotoxic, trypanocidal, anti-inflammatory, antidiabetic, gastric antisecretory, smooth muscle relaxant and antispasmolytic activities of this plant have also been reported (814).

Despite the wide spread usage of this plant in Nigerian and African ethnomedicine for the management of several health conditions, there is scarcity of information in literature on the toxicological implication of long term administration of this plant in humans or animals.

In the light of the above, the present study was designed to carry out acute and sub-acute toxicity studies on C. dolichopetalum leaves in experimental animals.

\section{Materials and methods}

\section{Collection and Identification of Plant Materials}

Fresh matured leaves of $C$. dolichopetalum were located and collected between February and March, 2017 from its natural habitat in Nsukka, Enugu State, Nigeria. The plant samples were identified by Mr. C.J. Onyeukwu, a taxonomist of the Plant Science \& Biotechnology Department of the University and the voucher specimen (UNH No.49a) of the plant was deposited at the herbarium.

\section{Preparation of extract}

The leaves were washed and air dried at room temperature for 7 days after which they were pulverized using an electric blender (model ms-233, China). The flour $(2 \mathrm{~kg}$ ) was extracted with methanol for $48 \mathrm{~h}$ in a Soxhlet extractor using the method of Jensen (2007). At the end of the extraction period, the extract was collected and concentrated $\left(40^{\circ} \mathrm{C}\right)$ to dryness after which it was weighed and thereafter constituted in the vehicle (distilled water) for acute and sub-chronic toxicity testing.

\section{Animal Experiments}

The animals that were used for this study were purchased from the Department of Veterinary Medicine, University of Nigeria, Nsukka.

Animal studies were done after ethical approval by the College of Medicine Research Ethics Committee, of the University of Nigeria, Enugu Campus, Enugu, Nigeria (protocol number: 026/02/2017) and which was in line with the ethical guidelines for the care and usage of laboratory animals as given by the National Institute of Health (15).

\section{Acute Toxicity Study}

The acute toxicity study was carried out following the OECD guideline 423 for testing of chemicals (16). Thirty healthy non preganant female Swiss albino mice were used for the acute toxicity study. Following acclimatization to their feeds and water, they were divided into 6 groups of 5 mice per group. The mice were administered graded oral doses of the extract (dissolved in distilled water) in the order: 500, 1000, 2000, 3000, 4000 and $5000 \mathrm{mg} / \mathrm{kg}$ body weight. Thereafter, they were kept in standard cages and allowed free access to feed and water ad libitum. Subsequently, they were observed for toxicity signs and the number of deaths in each group within $24 \mathrm{~h}$ for lethal dose $\left(\mathrm{LD}_{50}\right)$ calculation using the Karber's method, as reported by Enegide et al. (17) and Akomas et al. (18) respectively.

\section{Sub-acute Toxicity Study}

The sub-acute toxicity study on C. dolichopetalum was carried out following the OECD Guideline 407 (19) and it lasted for 21 days (20). Twenty five 
(25) mature inbred healthy non-pregnant female albino rats (weighing between 87.66 to $95.82 \mathrm{~g}$ ) of the Wistar strain were randomly grouped into five groups of five rats per group (one animal per cage) after acclimatization to their feeds and water. The rats in group I (Control) received distilled water while those in groups II, III, IV and V were administered 100, 200, 400 and $800 \mathrm{mg} / \mathrm{kg}$ respectively of $C$. dolichopetalum leaf extract (with distilled water as the vehicle) for 21 days using oral gavage. The rats were also kept in standard cages and they had access to their feeds and water ad libitum.

The changes in the weights of the rats were recorded on a daily basis. At the end of administration of the extract, the rats were fasted overnight (with access to only drinking water) and about $4 \mathrm{~mL}$ of blood samples were collected from the orbital route of each rat under mild ether anesthesia into anticoagulant tubes for the analysis of hematological parameters while the rest were poured into plain tubes for the assay of electrolytes, urea, creatinine, total and direct bilirubin, alkaline phosphatase (ALP), aspartate amino transaminase (AST) and alanine amino transaminase (ALT) activities respectively. The rats were later sacrificed by cervical dislocation and the liver and the kidneys were harvested and weighed (21). The body weights of the rats were recorded on a daily basis using an electronic weighing balance (Model Scout Pro, Ohaus Corporation, USA), and the changes in their weights were expressed as a percentage using the formula:

Percentage change in weight $=[$ Final weight Initial weight]/[Final weight] $\mathrm{x} 100$.

The relative organ weights were also expressed as a percentage using the formula:

Relative liver weight $=[$ Liver weight $] /[$ Final body weight] x100 and

Relative kidney weight $=[$ Kidney weight $] /[$ Final body weight] x100 (21).

\section{Haematological parameters}

The red blood cell count (RBC), packed cell volume (PCV), haemoglobin concentration (HGB), mean cell volume (MCV), mean cell haemoglobin $(\mathrm{MCH})$, mean cell haemoglobin concentration (MCHC), white blood cell count (WBC), and platelets count (PLT) were analyzed using Coulter ${ }^{\mathrm{B}}$ Ac-T 5Diff AL, Beckman Coulter, Inc. Port Matilda, Pennsylvania, USA.

\section{Liver function assays}

The total bilirubin, direct bilirubin, ALT, AST and ALP activities in the sera of the rats were determined with their respective kits (Biosystems kit) using A25 Biosystem Fully Automated Machines.

\section{Kidney function assays}

Sodium, potassium, chloride and bicarbonate were estimated with Easylyte ${ }^{\circledR}$ analyzer Medica Corporation, Bedford, USA while urea and creatinine were analyzed with their kits (Biosystems kit) using A25 Biosystem Fully Automated Machine.

\section{Histology}

The harvested organs were preserved in buffered $10 \%$ formalin saline solution for histopathological processing. They were washed in ascending grades of ethanol, cleared with xylene, embedded in paraffin wax. The tissues were finally sectioned using a rotary microtome (at $5 \mu$ thickness), stained with haematoxylin and eosin (H\&E) and mounted on Canada balsam. All the sections were examined microscopically using standard techniques. The slides were examined under a light microscope using X 200 magnification. Photomicrographs of lesions were taken with an Olympus photo microscope for observations and documentation of histopathological lesions (22).

\section{Statistical Analysis}

Statistical analysis was carried out by the use of Microsoft Excel Statistical Packages (Microsoft Corporations, USA). All analyses were carried out in triplicates and the results were presented as means and standard deviation. One-way analysis of variance was used for comparison of the means. Differences between means were considered to be significant when $\mathrm{P}<0.05$.

\section{Results}

\section{General signs and mortality}

There were neither behavioral changes nor signs of toxicity after administration of all the doses of the extract. The mice had normal disposition and were emotionally stable and all survived the 24 
Table 1: Body weights of rats

\begin{tabular}{lcccc}
\hline Groups & $\begin{array}{c}\text { Body weight before ad- } \\
\text { ministration }(\mathrm{g})\end{array}$ & $\begin{array}{c}\text { Body weight after ad- } \\
\text { ministration }(\mathrm{g})\end{array}$ & $\begin{array}{c}\text { Body weight } \\
\text { gain }(\mathrm{g})\end{array}$ & $\begin{array}{c}\text { \% change in body } \\
\text { weight }\end{array}$ \\
\hline Control & $91.38 \pm 3.40$ & $153.10 \pm 0.59$ & $61.72 \pm 1.64$ & $40.31 \pm 1.15$ \\
$\mathrm{II}(100 \mathrm{mg} / \mathrm{kg})$ & $92.18 \pm 2.10$ & $137.10 \pm 1.82^{*}$ & $44.92 \pm 0.64^{*}$ & $32.76 \pm 0.06^{*}$ \\
III $(200 \mathrm{mg} / \mathrm{kg})$ & $91.26 \pm 3.60$ & $132.20 \pm 1.49^{*}$ & $40.94 \pm 1.01^{*}$ & $30.97 \pm 0.02^{*}$ \\
IV $(400 \mathrm{mg} / \mathrm{kg})$ & $92.42 \pm 3.40$ & $126.00 \pm 1.12^{*}$ & $34.19 \pm 0.61^{*}$ & $26.65 \pm 0.08^{*}$ \\
V $(800 \mathrm{mg} / \mathrm{kg})$ & $91.61 \pm 2.10$ & $123.12 \pm 0.93^{*}$ & $32.21 \pm 0.93^{*}$ & $25.59 \pm 1.06^{*}$ \\
\hline
\end{tabular}

Values are reported as means $\pm \mathrm{SD},{ }^{*}=\mathrm{p}<0.05$ versus control

Table 2: Effect of $C$. dolichopetalum leaf extract on haematological parameters in rats

\begin{tabular}{|c|c|c|c|c|c|}
\hline Groups Parameters & Control & II(100mg/kg) & III(200mg/kg) & IV(400mg/kg) & $\mathrm{V}(800 \mathrm{mg} / \mathrm{kg})$ \\
\hline WBC $\times 10^{9} / \mathrm{L}$ & $10.46 \pm 0.78$ & $12.70 \pm 0.76^{*}$ & $14.12 \pm 0.42 *$ & $15.60 \pm 0.22^{*}$ & $18.78 \pm 0.66^{*}$ \\
\hline Neutrophils (\%) & $20.20 \pm 0.66$ & $31.20 \pm 0.66^{*}$ & $36.60 \pm 0.51^{*}$ & $40.40 \pm 0.51 *$ & $44.00 \pm 1.18^{*}$ \\
\hline Lymphocytes (\%) & $78.40 \pm 0.85$ & $66.60 \pm 0.85^{*}$ & $61.00 \pm 0.73^{*}$ & $57.00 \pm 0.94 *$ & $52.60 \pm 0.93^{*}$ \\
\hline Monocytes (\%) & $1.40 \pm 0.50$ & $2.20 \pm 0.10$ & $2.40 \pm 0.15$ & $2.60 \pm 0.30$ & $2.70 \pm 0.25$ \\
\hline RBC X 1012/L & $9.37 \pm 0.20$ & $9.94 \pm 0.70^{*}$ & $10.28 \pm 0.72^{*}$ & $11.44 \pm 0.12^{*}$ & $12.56 \pm 1.15^{*}$ \\
\hline $\mathrm{PCV}(\mathrm{L} / \mathrm{L})$ & $42.02 \pm 0.30$ & $43.00 \pm 0.33$ & $43.80 \pm 0.15^{*}$ & $43.90 \pm 0.14^{*}$ & $44.32 \pm 0.33^{*}$ \\
\hline HGB (g/dL) & $14.00 \pm 0.09$ & $14.33 \pm 0.13$ & $14.60 \pm 0.10^{*}$ & $14.62 \pm 0.05^{*}$ & $14.77 \pm 0.12^{*}$ \\
\hline $\operatorname{MCV}(\mathrm{fL})$ & $49.12 \pm 0.24$ & $50.12 \pm 0.06^{*}$ & $50.24 \pm 0.04 *$ & $50.30 \pm 0.09 *$ & $50.46 \pm 0.17^{*}$ \\
\hline $\mathrm{MCH}(\mathrm{pg})$ & $18.10 \pm 0.08$ & $18.36 \pm 0.02$ & $18.70 \pm 0.05^{*}$ & $18.42 \pm 0.04 *$ & $18.45 \pm 0.15$ \\
\hline $\mathrm{MCHC}(\mathrm{g} / \mathrm{dl})$ & $37.36 \pm 0.14$ & $37.78 \pm 0.12$ & $37.99 \pm 0.14$ & $38.18 \pm 0.19$ & $38.32 \pm 0.11$ \\
\hline $\operatorname{PLT} \times 10^{9} / \mathrm{L}$ & $684.20 \pm 5.94$ & $684.60 \pm 6.12$ & $685.60 \pm 5.33$ & $686.10 \pm 6.22$ & $687.40 \pm 6.54$ \\
\hline
\end{tabular}

Values are reported as means $\pm \mathrm{SD},{ }^{*}=\mathrm{p}<0.05$ versus control

Table 3: Effect of $C$. dolichopetalum leaf extract on markers of renal function in rats

\begin{tabular}{lccccc}
\hline Groups Parameters & Control (distilled water) & II $(100 \mathrm{mg} / \mathrm{kg})$ & $\mathrm{III}(200 \mathrm{mg} / \mathrm{kg})$ & $\mathrm{IV}(400 \mathrm{mg} / \mathrm{kg})$ & $\mathrm{V}(800 \mathrm{mg} / \mathrm{kg})$ \\
\hline Sodium $(\mathrm{mEq} / \mathrm{L})$ & $140.80 \pm 0.97$ & $140.92 \pm 0.80$ & $141.62 \pm 0.91$ & $141.70 \pm 0.67$ & $141.84 \pm 0.98$ \\
Potassium $(\mathrm{mEq} / \mathrm{L})$ & $4.08 \pm 0.10$ & $4.12 \pm 0.16$ & $4.15 \pm 0.10$ & $4.22 \pm 0.16$ & $4.23 \pm 0.10$ \\
Chloride $(\mathrm{mEq} / \mathrm{L})$ & $100.18 \pm 0.30$ & $100.41 \pm 0.36$ & $100.78 \pm 0.60$ & $100.81 \pm 0.51$ & $101.50 \pm 0.79$ \\
Bicarbonate $(\mathrm{mEq} / \mathrm{L})$ & $15.58 \pm 1.81$ & $17.52 \pm 2.05$ & $17.74 \pm 2.02$ & $18.92 \pm 2.46$ & $18.46 \pm 2.30$ \\
Urea $(\mathrm{mg} / \mathrm{dL})$ & $7.30 \pm 0.66$ & $6.32 \pm 0.47$ & $7.04 \pm 0.30$ & $6.32 \pm 0.47$ & $7.82 \pm 0.54$ \\
Creatinine $(\mathrm{mg} / \mathrm{dL})$ & $1.46 \pm 0.23$ & $1.42 \pm 0.08$ & $1.47 \pm 0.22$ & $1.54 \pm 0.05$ & $1.71 \pm 0.18$ \\
\hline
\end{tabular}

Values are reported as means $\pm \mathrm{SD}$

Table 4: Effect of $C$. dolichopetalum leaf extract on markers of liver function in rats

\begin{tabular}{lccccc}
\hline Groups Parameters & Control (distilled water) & $\mathrm{II}(100 \mathrm{mg} / \mathrm{kg})$ & $\mathrm{III}(200 \mathrm{mg} / \mathrm{kg})$ & $\mathrm{IV}(400 \mathrm{mg} / \mathrm{kg})$ & $\mathrm{V}(800 \mathrm{mg} / \mathrm{kg})$ \\
\hline Total bilirubin $(\mathrm{mg} / \mathrm{dL})$ & $5.06 \pm 0.78$ & $5.02 \pm 0.50$ & $5.44 \pm 0.68$ & $5.68 \pm 0.19$ & $5.62 \pm 0.92$ \\
Conjugated bilirubin $(\mathrm{mg} / \mathrm{dL})$ & $2.56 \pm 0.34$ & $2.38 \pm 0.30$ & $2.36 \pm 0.37$ & $2.44 \pm 0.33$ & $2.50 \pm 0.67$ \\
ALT (U/L) & $18.02 \pm 2.61$ & $15.62 \pm 2.37$ & $16.96 \pm 2.49$ & $15.78 \pm 0.33$ & $15.06 \pm 3.78$ \\
AST (U/L) & $26.02 \pm 4.20$ & $25.72 \pm 4.35$ & $22.44 \pm 4.76$ & $22.64 \pm 4.07$ & $22.28 \pm 4.19$ \\
ALP (U/L) & $197.80 \pm 0.50$ & $198.18 \pm 0.53$ & $198.88 \pm 0.89$ & $198.98 \pm 0.70$ & $199.16 \pm 0.75$ \\
\hline
\end{tabular}

Values are reported as means $\pm \mathrm{SD}$

Table 5: Effect of $C$. dolichopetalum leaf extract on some relative organ weight in rats

\begin{tabular}{llllll}
\hline Groups Parameters & Control & II $(100 \mathrm{mg} / \mathrm{kg})$ & $\mathrm{III}(200 \mathrm{mg} / \mathrm{kg})$ & $\mathrm{IV}(400 \mathrm{mg} / \mathrm{kg})$ & $\mathrm{V}(800 \mathrm{mg} / \mathrm{kg})$ \\
\hline Liver (\%) & $4.14 \pm 0.02$ & $4.11 \pm 0.03$ & $4.12 \pm 0.01$ & $4.13 \pm 0.02$ & $4.12 \pm 0.02$ \\
Kidney (\%) & $0.71 \pm 0.01$ & $0.72 \pm 0.01$ & $0.72 \pm 0.01$ & $0.73 \pm 0.02$ & $0.73 \pm 0.02$ \\
\hline
\end{tabular}

Values are reported as means $\pm \mathrm{SD}$ 
hours period of acute toxicity study. There were neither changes in the sensory nervous system responses nor adverse gastrointestinal effects. The oral administration of the extract up to the dose of $5000 \mathrm{mg} / \mathrm{kg}$ did not lead to $50 \%$ of mortality in mice. The $\mathrm{LD}_{50}$ of the extract was obtained as more than $5000 \mathrm{mg} / \mathrm{kg}$ body weight orally.

\section{Body weights of rats}

Table 1 shows the effect of administration of C. dolichopetalum leaf extract on the body weight of rats. Data presented in the Table revealed that there were no significant differences $(P>0.05)$ in the body weights of groups II to $\mathrm{V}$ rats relative to the control before extract administration. However, after extract administration, the body weights of groups II, III, IV and V rats (that recorded 32.76, $30.97,26.65$ and $25.59 \%$ increases in weights) were significantly lower than that of the control group (that recorded $40.31 \%$ gain in weight).

\section{Hematological parameters}

The effect of administration of C. dolichopetalum leaf extract on the haematological parameters of rats is shown in Table 2. Data presented in the Table showed that there were significant increases $(\mathrm{P}<0.05)$ in the white blood cells of groups II to $\mathrm{V}$ rats relative to the control (Table 2 ).

Significant increase $(\mathrm{P}<0.05)$ was observed in the neutrophils levels of groups II to $\mathrm{V}$ rats compared with the control (Table 2).

There were decreases $(\mathrm{P}<0.05)$ in the lymphocyte levels of groups II to $\mathrm{V}$ rats compared with the control; but no significant differences $(\mathrm{P}>0.05)$ in the monocyte levels of groups II to $\mathrm{V}$ rats relative to the control (Table 2).

There were significant increases $(\mathrm{P}<0.05)$ in the red blood cells of groups II to $\mathrm{V}$ rats compared with the control; significant increases $(P<0.05)$ in the PCV of groups III to V rats compared with the control but no difference $(\mathrm{P}>0.05)$ in the PCV of group II rats compared with the control (Table 2).

There were significant increases $(\mathrm{P}<0.05)$ in the hemoglobin levels of groups III to V compared with the control, but no difference $(P>0.05)$ in the hemoglobin levels of group II rats compared with the control (Table 2).

There were significant increases $(\mathrm{P}<0.05)$ in the $\mathrm{MCV}$ of groups II to $\mathrm{V}$ compared with the control; significant increases $(\mathrm{P}<0.05)$ in the $\mathrm{MCH}$ of groups III to $\mathrm{V}$ compared with the control but no difference $(\mathrm{P}>0.05)$ in the $\mathrm{MCH}$ of group II rats compared with the control.

There were no differences $(\mathrm{P}>0.05)$ in the $\mathrm{MCHC}$ of groups II to $\mathrm{V}$ when compared with the control and no differences $(\mathrm{P}>0.05)$ in the PLT of groups II to $\mathrm{V}$ rats compared with the control.

\section{Renal Function Parameters}

Table 3 shows the effect of administration of C. dolichopetalum leaf extract on markers of renal function in rats. As shown in the Table, there were no significant differences $(\mathrm{P}>0.05)$ in the serum levels of $\mathrm{Na}^{+}, \mathrm{K}^{+}, \mathrm{Cl}^{-}, \mathrm{HCO}_{3}^{-}$, urea and creatinine in groups II to $\mathrm{V}$ rats when compared with the control.

\section{Liver Function Parameters}

The effect of administration of C. dolichopetalum leaf extract on markers of hepatic function in rats is shown in Table 4. As shown in the Table, there were no significant differences $(P>0.05)$ in the serum levels of total and direct bilirubin and the activities of ALT, AST and ALP in the sera of groups II to V rats compared with the control.

\section{Relative Organ Weights}

The effect of administration of C. dolichopetalum leaf extract on some relative organ weight in rats is shown in Table 5 . As shown in the Table, there were no significant differences $(\mathrm{P}>0.05)$ in the relative liver weights of groups II to $\mathrm{V}$ rats when compared with the control.

Similarly, there were no significant differences $(\mathrm{P}>0.05)$ in the relative kidney weights of groups II to $\mathrm{V}$ rats relative to the control.

\section{Histology}

The results of the histopathological assay of the liver and kidney of the rats that were investigated in this study are shown in Figures 1 and 2. A section of the liver from the control and treated groups showed normal arrangement of the hepatocytes (liver cells) in cords. The architecture of the portal triad comprising of the bile duct, hepatic portal vein and hepatic arteries were all 

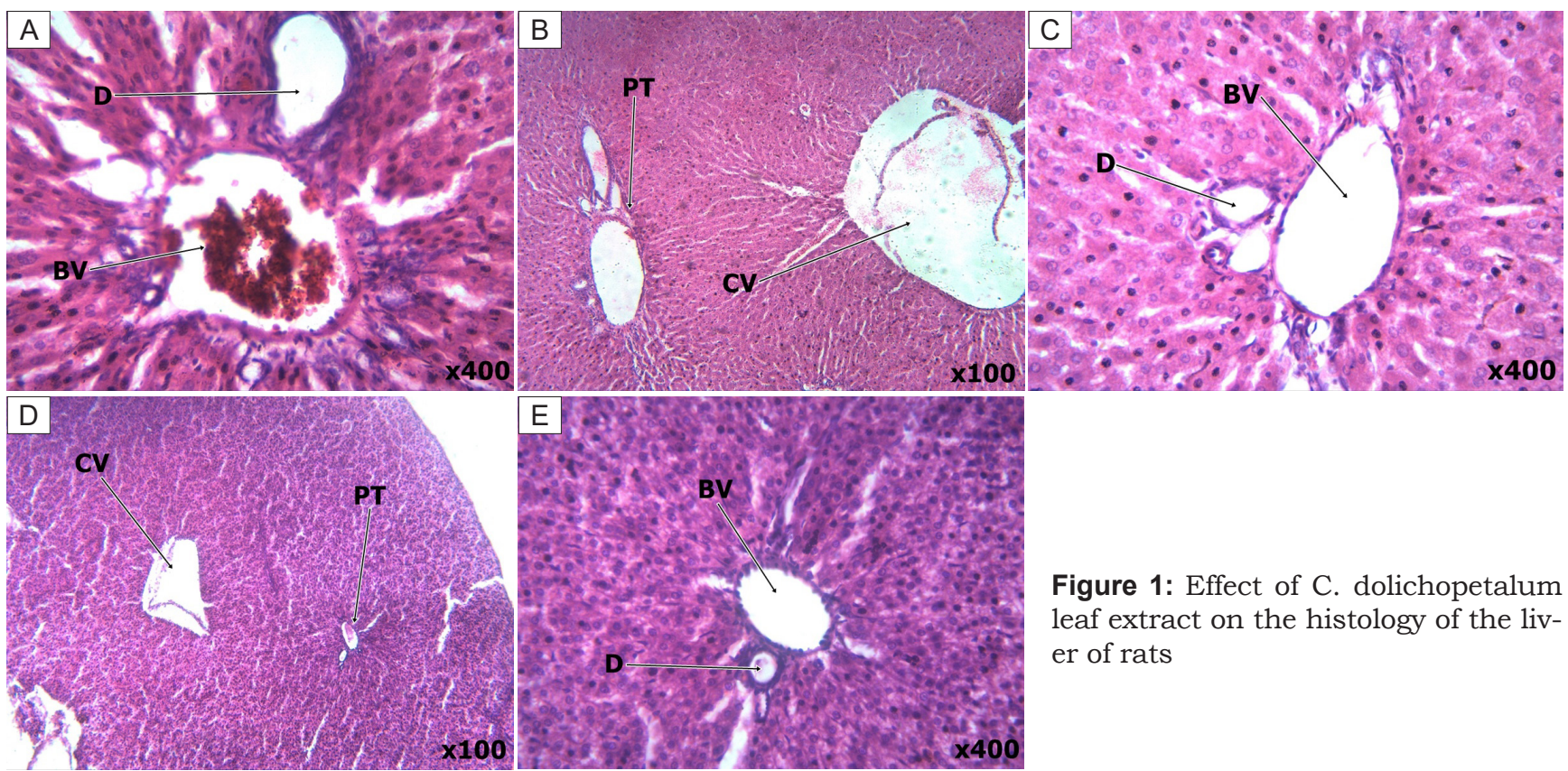

Figure 1: Effect of C. dolichopetalum leaf extract on the histology of the liver of rats

A: (Control group) Photomicrograph showing a well preserved liver architecture. The portal triads are evenly spaced around a central vein and there is no portal inflammation. (BV-blood vessel, D-ductule); B: (Group II) Photomicrograph showing a well preserved liver architecture. No inflammatory cells were seen. (PT - Portal triad, CVCentral vein); C: (Group III) Photomicrograph showing a well preserved liver architecture. No inflammatory cells were seen. No visible lesion seen. (BV-blood vessel, D-ductule); D: (Group IV) Photomicrograph showing a well preserved liver architecture. No inflammatory cells were seen. No visible lesion seen. (BV-blood vessel, D-ductule); E: (Group V) Photomicrograph showing a well preserved liver architecture. No inflammatory cells were seen. No visible lesion seen. (PT - Portal triad, CV- Central vein)
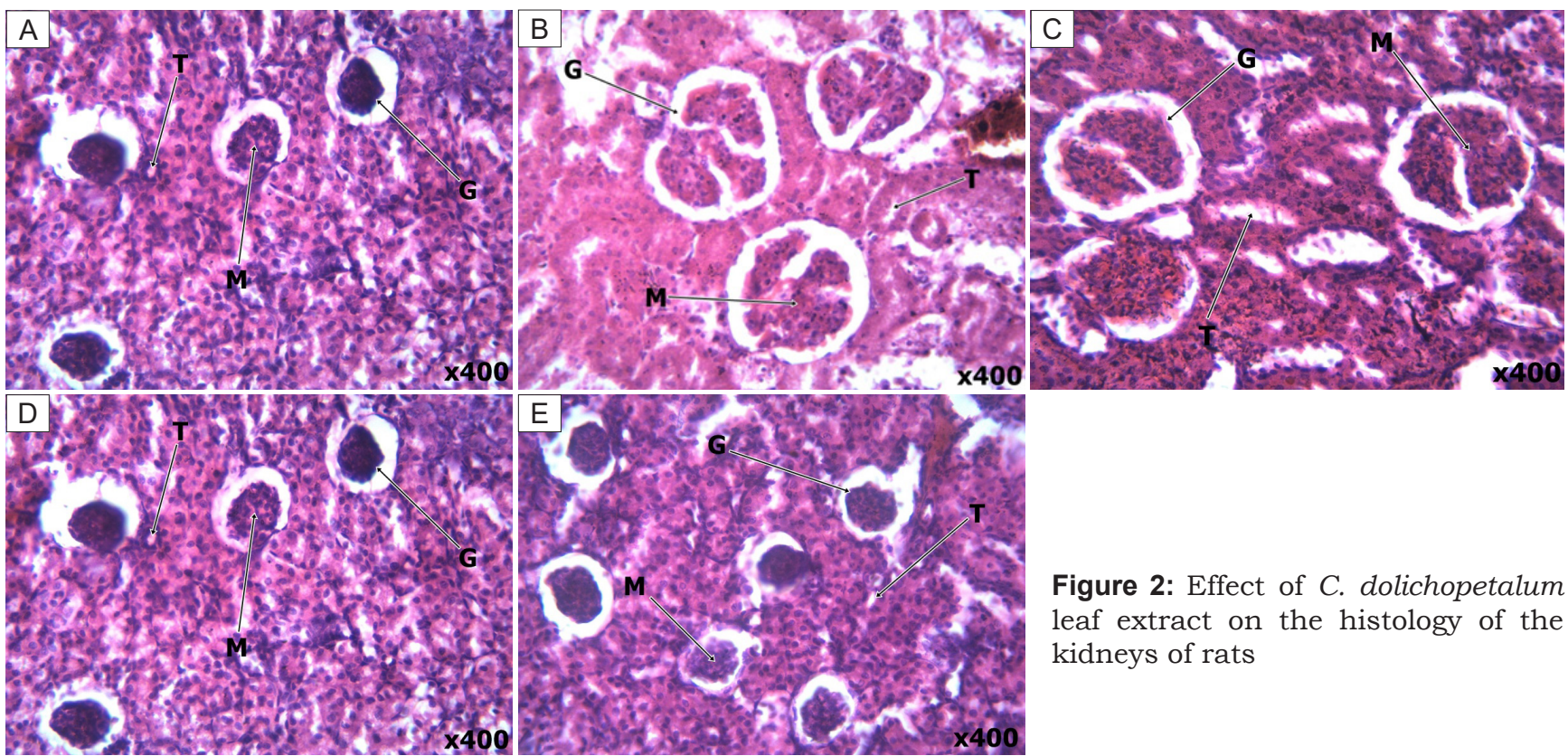

Figure 2: Effect of C. dolichopetalum leaf extract on the histology of the kidneys of rats

A: (Control group) Photomicrograph showing an evenly distributed glomeruli, of similar size, with normal mesangial cellularity. There are numerous open glomerular capillaries, and normal endothelium. The tubules are of normal density and tubular epithelium is viable. (M= mesangium, $\mathrm{G}=$ glomerulus, $\mathrm{T}=$ tubule)s; $\mathrm{B}$ : (Group II) Photomicrograph showing a well preserved kidney architecture. No visible lesion seen. . (M= mesangium, $G=$ glomerulus, $T=t u b u l e)$; C: (Group III) Photomicrograph showing a well preserved kidney architecture. No visible lesion seen. (M= mesangium, G=glomerulus, T=tubule); D: (Group IV) Photomicrograph showing a well preserved kidney architecture. No visible lesion seen. ( $\mathrm{M}=$ mesangium, $\mathrm{G}=$ glomerulus, $\mathrm{T}=$ tubule) $\mathrm{E}$ : (Group V) Photomicrograph showing a well preserved kidney architecture. No visible lesion seen. $(\mathrm{M}=$ mesangium, $\mathrm{G}=$ glomerulus, $\mathrm{T}=$ tubule $)$ 
normal. The central veins were also found to be normal. No inflammatory cells were seen in the connective tissue of the portal triad. No necrosis was also observed and the central vein showed no form of congestion and no infiltration with inflammatory cells.

The kidneys in both the control and all the treated groups were normal showing numerous renal tubules interstitials tissues and no signs of inflammations. The glomerulus and renal vein and artery also appeared normal.

\section{Discussion}

General behavior is amongst the parameters that are necessary for the assessment of first signs of toxicity (5). The acute toxicity study which revealed that the extract did not affect the general behaviours of the mice, suggests that the extract was well tolerated by the mice.

According to previous reports $(22,23)$, a substance with an $\mathrm{LD}_{50}$ of $1000 \mathrm{mg} / \mathrm{kg}$ body weight and above could be regarded to be safe for administration. The high $\mathrm{LD}_{50}$ that was obtained in this study for this plant therefore suggests its non-toxicity and the safety of its usage in herbal medicine. Going by the globally harmonized classification system for chemical substances and mixtures as given by the OECD (24), the $\mathrm{LD}_{50}$ that was obtained for the extract suggests the extract to fall under class 5 drug and as such, could be considered to be non toxic (1).

In addition to general behavior, changes in body weights are also considered as parameters that are of great importance for the evaluation of first signs of toxicity $(6,17,22-23)$. Although the sub-acute toxicity study revealed that all the rats that were administered the extract had lower body weights compared with the control, when comparisons were made between before and after extract administration, it was observed that all the rats administered the extract recorded significant increases in body weights compared with their body weights before extract administration. This finding therefore suggests that the extract positively impacted on the normal growth of the rats. However, the decreased body weights of the rats administered the extracts when compared with the controls, may be attributed to improved feed consumption by the rats in the control group due perhaps to preference for the control diets over the extract.
Toxic compounds have the hematopoietic system as one of their targets which makes the hematopoietic system a crucial marker of physiological and pathological state in both humans and animals (5, 20, 25-31).

The increased WBC, Neutrophils, RBC, PCV, $\mathrm{HGB}, \mathrm{MCV}$ and $\mathrm{MCH}$ of the rats administered the extract as observed in this study suggests that the extract is likely to stimulate hematopoiesis.

The non significant differences in the Monocytes, MCHC and PLT of the rats administered the extract at all doses when compared with the control suggests that administration of the extract at all the doses had no effect on the Monocytes, MCHC and PLT counts of the rats. Furthermore, findings of this study also showed that administration of the extract at $100 \mathrm{mg} / \mathrm{kg}$ had no effect on the packed cell volume and haemoglobin levels of the rats suggesting that the extract at this concentration was not able to initiate erythropoiesis in the rats. In all, the study revealed that administration of the extract had no toxicological effect on the haematopoietic system of the rats.

The kidneys receive about $25 \%$ of the cardiac blood flow and any substance that reaches the systemic circulation will reach the kidney. This therefore makes the kidneys quite vulnerable to to toxic compounds $(1,20,32-34)$.

Renal function in this study was evaluated by serum levels of $\mathrm{Na}^{+}, \mathrm{K}^{+}, \mathrm{Cl}^{-}, \mathrm{HCO}_{3}^{-}$, urea and creatinine and by histological analysis.

Electrolytes play important roles in many body processes some of which include: control of fluid levels, acid-base balance, etc. In the event of renal impairment/disease, these functions of electrolytes could be grossly affected.

The major cation in the extracellular fluid is $\mathrm{Na}^{+}$and it plays an essential role in maintaining the water balance in the body and regulating the extracellular fluid volume (35-36). $\mathrm{K}^{+}$is the most abundant cation in the intracellular fluid and it is useful in the maintenance of osmotic pressure (35-36). $\mathrm{Cl}^{-}$is the main anion that is found in the extracellular fluid and it aids the body to balance as well as maintain osmotic pressure and electrical neutrality. $\mathrm{HCO}_{3}{ }^{-}$is an important anion of the bicarbonate buffer system (35-36).

Urea which is formed in the liver as an end product of protein metabolism is thereafter eliminated by the kidneys (35). In the event of renal impairment or disease, the rate of elimination of urea by the kidneys will be affected leading to in- 
creased blood levels of urea. Creatinine is a waste product that is derived from creatine phosphate in a non-enzymatic and spontaneous reaction. Creatinine is removed from the blood mainly by the kidneys by glomerular filtration and by proximal tubular secretion with little or no reabsorption. Hence, in the event of defective filtration by the kidneys due perhaps to renal impairment or disease, the tendency will be increased blood concentration of creatinine (35). Therefore, urea and creatinine are quite useful in evaluating kidney function.

In this study, the extract at all the doses administered had no effect on the concentrations of $\mathrm{Na}^{+}, \mathrm{K}^{+}, \mathrm{Cl}^{-}, \mathrm{HCO}_{3}^{-}$, urea and creatinine levels of the rats suggesting that the extract did not induce alteration in renal functions of the rats or induce kidney damage. These findings therefore indicate the non-toxicity of the extract to the kidney of the rats.

The liver is an important organ that plays a crucial role in the detoxification drugs and its normal function could be assessed by the concentrations or activities of various biomarker molecules/enzymes in the sera.

Bilirubin is a product of haemoglobin degradation, and increases in its serum levels are attributed to illnesses such as primary biliary cirrhosis, jaundice and hepatic cholestasis (1). ALT catalyzes the transfer of an a-amino group from alanine to $\mathrm{a}-\mathrm{KT}$ to form glutamate and pyruvate respectively. The liver is the major source of this enzyme and its level in the sera increases during liver pathology. AST level, apart from being an indicator of liver dysfunction, is also used to assess muscle and heart diseases (35). ALP is mainly found in the cells lining the biliary duct of the liver and it is used in the diagnosis of bile duct pathologies (35). In addition, assay of the activities of aminotransferases and phosphatases is considered to be of clinical and toxicological importance as changes in their activities could indicate disease state or tissue damage by toxicants (37).

Findings of this study showed that the extract did not elicit significant changes in the levels of total and direct bilirubin as well as the activities of ALT, AST, and ALP in the rats, suggesting the non-hepatoxic action of the extract as well as its non-adverse effect on erythropoiesis.

Organ weight has been considered to be a very reliable and about the most sensitive indicator of the effect of drug toxicity $(22,38-39)$. This is because significant changes in organ weights between treated and control animals could occur in the absence of any morphological changes or may precede morphological changes $(20,39)$. In this study, the extract at all the doses administered had no effect on the relative weights of the liver and kidney of the rats, which further affirms the non-toxicity of the extract to the liver and kidney of the rats.

The results of the histology of the kidney and liver of the control rats and the rats administered the extract which results corroborate the results of the liver and kidney function assays and the relative liver and kidney weights of the rats, is a confirmation that administration of the extract to the rats did not induce any form of hepatic or renal toxicity.

\section{Conclusion}

The present study demonstrated the safety in the traditional usage of combretum dolichopetalum leaves in Nigerian ethnomedicine in the maintenance of health and treatment of various diseases.

\section{Acknowledgements}

The authors declare that they have no conflict of interest.

The authors wish to thank the technical staff of the Department of Physiology, Alex Ekwueme Federal University, Ikwo, Ebonyi State, Nigeria for their assistance.

\section{References}

1. El Kabbaoui M, Chda A, El-Akhal J, et al. Acute and sub-chronic toxicity studies of the aqueous extract from leaves of Cistus ladaniferus L. in mice and rats. J Ethnopharmacol 2017; 209: 147-56.

2. Yuan H, Ma Q, Ye L, Piao G. The traditional medicine and modern medicine from natural products. Molecules 2016; 21: 559.

3. Han JS, Lee BS, Han SR, et al. A subchronic toxicity study of Radix Dipsaci water extract by oral administration in F344 rats. Regul Toxicol Pharmacol 2016; 81: 136-45.

4. Yuet Ping K, Darah I, Chen Y, Sreeramanan 
S, Sasidharan S. Acute and subchronic toxicity study of Euphorbia hirta L. methanol extract in rats. BioMed Res Int 2013; 2013: e182064. doi: 10.1155/2013/182064

5. Ezeja MI, Anaga AO, Asuzu IU. Acute and sub-chronic toxicity profile of methanol leaf extract of Gouania longipetala in rats. J Ethnopharmacol 2014; 151: 1155-64.

6. Uzor PF, Osadebe PO, Omeje EO, Agbo MO. Bioassay guided isolation and evaluation of the antidiabetic principles of Combretum dolichopetalum root. Br J Pharm Res 2014; 4: 2155-71.

7. Burkhill HM. The useful plants of West Tropical Africa. 2nd ed. Vol. 1, Families A-D. Kew : Royal Botanic Gardens, 1985: 960.

8. Asuzu IU, Onu OU. Anti-ulcer activity of the ethanolic extract of Combretum dolichopetalum roots. Int J Crude Drug Res 1990; 28: 27-32.

9. Udem SC, Madubunyi I, Okoye JO, Anika SM. Anti-hepatotoxic effects of the ethanolic extracts of Combretum dolichopetalum root bark and Morinda lucida leaf. Fitoterapia 1997; 68: 21-4.

10. Barku VYA, Opoku-Boahen, Dali, G. Ethnobotanical study of wound healing plants in kpando traditional area, Ghana. Int J Phytomed 2014; 6: 564-72.

11. Ameyaw Y, Barku VYA, Ayivor J, Forson A. Phytochemical screening of some indigenous medicinal plant species used in the management of diabetes mellitus in Ghana. J Med Plants Res 2012; 6: 4573-81.

12. Onoja SO, Udeh NE. Antidiarrheal effects of hydromethanolic extract of Combretum dolichopetalum leaves in mice. J Coastal Life Med 2015; 3: 910-3.

13. Asuzu IU, Njoku JC, Njoku J. The pharmacological properties of the ethanolic root extract of Combretum dolichopetalum. Phytother Res 1992; 6: 125-8.

14. Asuzu IU, Adimorah RI. The anti-inflammatory activity of extracts from the root of Combretum dolichopetalum. Phytomedicine 1998; 5: 25-8.

15. National Research Council, NRC. Guide for the care and use of laboratory animals. Bethesda : National Institute of Health, 1985.

16. OECD. Guidelines for testing of chemicals no. 423. Acute oral toxicity - acute toxic class method. Paris : Organisation for Economic Co-Operation and Development, OECD, 2001.

17. Enegide C, David A, Fidelis SA. A new method for determining acute toxicity in animal models. Toxicol Int 2013; 20: 224-6.

18. Akomas SC, Ijioma SN, Emelike CU. In vivo and in vitro activity of ficussur ethanolic extract on the gastrointestinal tract. Br Biotechnol J 2014; 4: 1182-90.

19. OECD. Guidelines for testing of chemicals no. 407. Repeated dose 28-days oral toxicity study in rodents. Paris : Organisation for Economic Co-Operation and Development, OECD, 1995.

20. Marcela CA, Neila MS, Paula MV, et al. Acute and sub chronic toxicity study of aqueous extract from the leaves and branches of Campomanesia velutina (Cambess) O. Berg. J Ethnopharmacol 2017; 201: 17-25.

21. Eleazu CO, Okafor PN. Use of unripe plantain (Musa paradisiaca) in the management of diabetes and hepatic dysfunction in streptozotocin induced diabetes in rats. Interv Med Appl Sci 2015; 7: 9-16.

22. Kalu W, Okafor P, Ijeh I, Eleazu C. Effect of kolaviron, a biflavanoid complex from Garcinia kola on some biochemical parameters in experimentally induced benign prostatic hyperplasic rats. Biomed Pharmacother 2016; 83:1436-43.

23. Clarke EGC, Clarke ML. Veterinary toxicology. London : Casell and Collier Macmillan Publishers, 1977: 268-77.

24. OECD. Harmonised integrated classification system for human health and environmental hazards of chemical substances and mixtures. Paris : OECD, 2001: Chapter 2.1. (adopted 14th August 2001) (OECD Series on testing and assessment, No. 33.)

25. Lee MY, Shin IS, Seo CS, Kim JH, Han SR, Shi HK. Sub chronic oral toxicity studies of the traditional herbal formula Bangpunglongseong-an in Crl:CD (SD) rats. J Ethnopharmacol 2012; 144: $720-5$.

26. Thanabhorn S, Jaijoy K, Thamaree S, Ingkaninan K, Panthong A. Acute and subacute toxicity study of the ethanol extract from Locinera japonica Thunb. J Ethnopharmacol 2006; 107: 370-3.

27. Khan TA, Zafar F. Haematological study in response to varying doses of estrogen in broiler chicken. Int J Sci 2005; 4: 748-51.

28. Liju VB, Jeena K, Kuttan R. Acute and subchronic toxicity as well as mutagenic evaluation of essential oil from turmeric (Curcuma longa L). Food Chem Toxicol 2013; 53: 52-61.

29. Sunmonu TO, Oloyedem OB. Performance 
and haematological indices in rats exposed to monocrotophos contamination. Hum Exp Toxicol 2010; 29: 845-50.

30. Ugwuezumba PC, Nwankpa P, Emengaha $\mathrm{FC}$, et al. Alteration of haematological indices on administration of ethanol leaf and root extracts of sida acuta in albino wistar rats. Asian J Sci Technol 2018; 9: 8156-9.

31. Olson H, Betton G, Thomas D, et al. Concordance of the toxicity of pharmaceuticals in humans and in animals. Regul Toxicol Pharmacol 2000; 32: 56-67.

32. Dekant W, Vamvakas S. Biotransformation and membrane transport in nephrotoxicity. Crit Rev Toxicol 1996; 26: 309-34.

33. Akindele AJ, Adeneye AA, Salau OS, Sofidiya MO, Benebo AS. Dose and timedependent sub-chronic toxicity study of hydroethanolic leaf extract of Flabellaria paniculata Cav. (Malpighiaceae) in rodents. Front Pharmacol 2014; 5: e78. doi: 10.3389/fphar.2014.00078

34. Gowda S, Desai PB, Kulkarni SS, Hull VV, Math AAK, Vernekar SN. Markers of renal function tests. N Am J Med Sci 2010; 2: 170-3.

35. Nayak SB. Maniple manuel of clinical bio- chemistry. New Delhi : Jaypee Brothers, Medical Publishers, 2007: 300.

36. Achi N, Ohaeri C, Ijeh I, Eleazu C, Igwe K, Onyeabo C. Ameliorative potentials of methanol fractions of Cnidoscolus aconitifolius on some hematological and biochemical parameters in streptozotocin diabetic rats. Endocr Metab Immune Disord Drug Targ 2018; 18(6): 637-45.

37. Eleazu CO, Okafor PN, Ijeh I. Biochemical basis of the use of cocoyam (Colocassia esculenta L.) in the dietary management of diabetes and its complications in streptozotocin induced diabetes in rats. Asian Pac J Trop Dis 2014; 4: S705-S711.

38. Balogun SO, Da Silva IF, Colodel EM, De Oliveira RG, Ascêncio SD, Martins DO. Toxicological evaluation of hydroethanolic extract of Helicteres sacarolha A. J Ethnopharmacol 2014; 157: 285-91.

39. Ying P, Yunen L, Xiaodong X. Change trends of organ weight background data in Sprague Dawley rats at different ages. J Toxicol Pathol 2013; 26: 29-34.

\title{
AKUTNA IN SUBAKUTNA ŠTUDIJA TOKSIČNOSTI LISTOV RASTLINE Combretum dolichopetalum
}

\author{
C.U. Emelike, U.S.B. Anyaehie, E.E. Iyare, C.A. Obike, C. Eleazu, C. Chukwu
}

Povzetek: S standardnimi metodami smo pri poskusnih miših in podganah proučevali akutno in subakutno toksičnost listov Combretum dolichopetalum. LD50 metanolnega izvlečka listov Combretum dolichopetalum je bil pri poskusnih miših nad 5000 mg/kg telesne teže. Enaindvajsetdnevno dodajanje naraščajočih odmerkov (100, 200, 400 in 800 mg/kg) izvlečka je pri poskusnih podganah povzročilo povečanje telesne mase, števila belih krvničk (WBC), nevtrofilcev, rdečih krvničk (RBC), volumna stisnjenih eritrocitov (PCV), hemoglobina (HGB), povprečnega volumna eritrocitov (MCV) in povprečno vsebino hemoglobina v eritrocitih $(\mathrm{MCH})$, ni pa vplivalo $(p>0,05)$ na število monocitov, povprečno koncentracijo hemoglobina vvolumnu eritrocitov (MCHC) ter na povprečno vrednost trombocitov (PLT). Nobeden od odmerkov izvlečka ni vplival na $(p>0,05)$ vrednosti natrija, kalija, klorida, bikarbonata, sečnine, kreatinina, skupnega bilirubina in vezanega bilirubina, alanina, aspartatne amino transaminaze, aspartatne amino transaminaze, alkalne fosfataze; relativno težo jeter in ledvic podgan, karje bilo v skladu s histološko preiskavo jeter in ledvic. Izvleček vodmerku 100 mg/kg ni vplival na PCV in HB podgan. Študija tako kaže na možnost uporabe rastline Combretum dolichopetalum za izboljšanje krvne slike. Raziskava je dokazala varnost uporabe listov Combretum dolichopetalum, ki se tradicionalno uporabljajo v Nigeriji v etnomedicini.

Ključne besede: etnofarmakologija; Combretum dolichopetalum; toksikologija; zeliščna zdravila; hranila; farmakoterapija 